\title{
PENEGAKAN HUKUM KEPEMILUAN UNTUK PEMILU BERMARTABAT
}

\author{
Junaidi Ahmad $^{(1)}$, Agmar Media ${ }^{(2)}$ \\ ${ }^{1,2}$ Ilmu Hukum, Universitas Jabal Ghafur, Kabupaten Pidie \\ e-mail: ahjunaidi94@gmail.com,bintangmeucahaya@gmail.com
}

\begin{abstract}
The notion of popular sovereignty and the rule of law must go hand in hand. As a characteristic of a modern state, democracy is manifested through general elections with integrity. Law enforcement and election justice are the principles and formulas for elections with integrity. The independence of the organizing agency, transparent and accountable will foster people's trust as the holder of the right to vote. Elections with integrity give birth to legitimacy for every representative elected in the voting booth. Maintaining the people's right to vote through law enforcement is the absolute responsibility of all stakeholders when the General Election takes place.
\end{abstract}

Keywords :Law Enforcement, Election, Dignified

\begin{abstract}
ABSTRAK
Paham kedaulatan rakyat dan kedaulatan hukum mestilah berjalan secara beriringan. Sebagai ciri Negara modern, pengejewantahan demokrasi lewat Pemilihan Umum yang berintegritas.Penegakan hukum dan keadilan Pemilu menjadi asas dan formula pemilu berintegritas. Independensi lembaga penyelenggara, transparan dan akuntable akan menumbuhkan kepercayaan rakyat sebagai pemegang hak pilih. Pemilu berintegritas melahirkan legimitasi bagi setiap perwakilan yang pilih di bilik suara.Menjaga hak pilih rakyat lewat penegakan hukum adalah tanggung jawab mutlak seluruh pemangku kepentingan saat penyelenggaraan Pemilihan Umum berlangsung.
\end{abstract}

Kata kunci: Penegakan Hukum, Pemilu, Bermartabat

\section{Pendahuluan}

Suatu pemilu dikatakan sukses tidak hanya dilihat dari terlaksananya semua tahapan semata, terisinya semua jabatan atau posisi baik eksekutif maupun legeslatif adalah sebesar-besar tujuan penyelenggaraan Pemilihan umum. Sesuai dengan prinsip hukum, tidak dapat dikatakan sebagai Pemilu yang berhasil dan bermartabat jika mereka terpilih melalui cara-cara yang penuh dengan pelanggaran dan kecuarangan yang bertentangan dengan asas Langsung, Umum, Bebas, Rahasia (LUBER) dan Jujur, Adil (JURDIL).

Asas langsung, umum, bebas, dan rahasia terkait dengan cara pemilih menyampaikan suaranya, yaitu harus secara langsung tanap diwakilkan, berlaku umum bagi semua warga Negara yang telah memenuhi syarat sebagai pemilih, dilakukan secara bebnas tanpa adanya paksaan, dan secara rahasia. Asas jujur mengandung arti 
bahwa Pemilu harus dilaksanakan sesuai dengan aturan untuk memastikan bahwa setiap warga Negara yang berhak memilih dapat memilih sesuia kehendaknya..dan setipa suara pemilih memiliki nilai yang sama untuk menentukan wakil rakyat yang akan terpilih. Sesuai dengan asas jujur, tidak boleh ada suara pemilih yang dimanipulasi. Sedangkan asas adil, adalah perlakuan yang sama terhadap semua peserta Pemilu dan pemilih, tanpa ada pengistimewaan ataupun diskriminasi terhadap peserta Pemilu atau pemilih tertentu.

Asas jujur dan adil mengikat tidak hanya kepada pemilih ataupun peserta Pemilu, tetapi juga penyelenggara Pemilu. Asas jujur dan adil tidak hanya terwujud mekanisme prosedural pelaksanaan Pemilu, tetapi juga harus terwujud dalam segala tindakan penyelenggara, peserta ,pemilih, bahkan pejabat pemerintah. Dengan demikian, asas jujur dan adil menjadi spirit seluruh pelaksanaan Pemilu.

Menurut Jimly Asshiddiqie, asas Luber menyangkut sifat objektif yang harus ada dalam proses pelaksanaan atau mekanisme Pemilu, terutama pada saat seseorang melaksanakan hak pilihnya. Sedangkan asas jurdil terutama terkait dengan sifat subjektif penyelenggara dan pelaksana Pemilu yang harus bertindak jujur dan adil (Jimly Asshiddiqie, 2002, Konsolidasi Naskah UUD 1945 setelah Perubahan Keempat, Jakarta, Pusat Stdi HTN FH UI).

Pemilu yang demokratis, berkualitas dan bermartabat dapat dicapai apabila semua tahapan Pemilu juga mencerminkan pengejewantahan kedaulatan rakyat sesuai dengan prinsip hukum dan asas-asas kepemiluan secara universal.

\section{Metode}

Jenis penelitian yang digunakan dalam penelitian ini adalah penelitian hukum normativ (yuridis normatif) yakni penelitian yang difokuskan untuk mengkaji penerapan kaidah kaidah atau norma-norma dalam hukum positif. Penelitian hukum normatif disebut juga penelitian hukum doktrinal, karena penelitian ini dilakukan atau ditujukan hanya pada peraturan-peraturan yang tertulis atau bahan hukum yang lain. Penelitian hukum ini juga disebut sebagai penelitian kepustakaan.Hal ini disebabkan karena penelitian lebih banyak dilakukan terhadap data yang bersifat sekunder yang ada di perpustakaan dan menggunakan pendekatan perundang-undangan (statute approach).

Dalam penelitian pada umumnya dibedakanantara data yang diperoleh secara langsung daribahan-bahan pustaka.Yang diperoleh dari bahan-bahan pustaka lazimnya dinamakan datasekunder.Sumber data dalam penelitian ini diperoleh dari data sekunder, yang terdiri dari:

a. Bahan hukum primer yaitu bahan-bahan hukum yang mengikat, yaitu undangundang dasar, undang-undang terkait pelaksanaan kepemiluan dan peraturan dibawah undang-undang.

b. Bahan hukum sekunder, yaitu bahanbahan yang erat hubungannya dengan bahan-bahan hukum primer yang dapat membantu menganalisa dan memahami bahan hukum primer seperti buku, tulisan para ahli dan hasil-hasil penelitian.

c. Bahan hukum tersier, yaitu bahan-bahan hukum yang memberikan informasi tentang bahan-bahan hukum primer dan sekunder seperti kamus, makalah, artikelartikel,majalah, koran dan internet.

\section{Hasil dan Pembahasan \\ Pemilu dan Perwujudan Nilai demokrasi}

Demokrasi berakar pada "demos" dalam bahasa Yunani kuno yang berarti suatu bentuk pemerintahan oleh suatu populasi yang berlawanan dengan kelompok kaya dan 
para aristocrat. Karena itu, dalam pengertian Yunani kuno demokrasi adalah kekuasaan oleh orang biasa, yang miskin dan tidak terpelajar, sehingga demokrasi pada saat itu. Misalnya oleh Aristoteles, ditempatkan sebagai bentuk pemerintahan yang merosot atau buruk ( N.D. Arora and S.S. Awasthy, 1999, Polical Theory, New Delhy, HarAnand, hlm.308).

Dimasa kini demokrasi juga tetap mendapatkan kritik. Philipe C. Schmitter dan Terry Lynn Karl menyebutkan empat kelemahan demokrasi ;

1. Demokrasi tidak dengan sendirinya lebih efisien secara ekonomis ketimbang bentuk bentuk pemerintahan lainnya;

2. Demokrasi tidak secara otomatis lebih efisien secara administratif. Kapasitas demokrasi untuk mengambil keputusan keputusan boleh jadi lebih lambat ketimbang rezim -rezim lain yang pernah digantikannya;

3. Demokrasi tidak mampu menunjukkan situasi yang lebih tertata rapi, penuh consensus, stabil, atau dapat memerintah ketimbang sisitem otokrasi yang mereka tumbangkan. Situasi semacam ini sulit dielakkan sebagai implikasi dari kebebasan berekpresi dalam demokrasi;

4. Demokrasi memang meungkinkan masyarakat dan kehidupan politik yang lebih terbuka ketimbang otokrasi yang disingkirkannya, akan tetapi tidak dengan sendirinya menjadikan ekonomi lebih terbuka (Janedjri M. Gaffar, Demokrasi dan Pemilu di Indonesia,2013, KonPres, hlm.15.)

Istilah demokrasi memang berakar dari Yunani pada masa Negara kota (city - state), tetapi model demokrasi modern tidak diperoleh disana. Asumsi dan praktek demokrasi pada saat itu sangat berbeda dengan demokrasi modern.Pada masa yunani kuno demokrasi tidak didirikan atas ide hak individu warga Negara. Hak ini hanya diberikan kepada sejumlah kecil warga Negara yang tinggal di dalam kota. Kata demokrasi dalam arti modern mulai digunakan pada abad xix untuk menunjuk sistem pemerintahan perwakilan di mana para wakil rakyat dipilih melalui pemilihan kompetitif yang bebas oleh warga Negara.

Secara umum, Pemilu yang demokratis adalah Pemilu yang dilakukan secara berkala, dan diselenggarakan berdasarkan prinsip bebas, serta jujur dan adil ( free and fair election) (J imly Asshiddiqie, Partai Politik dan Pemilihan Umum Sebagai Instrumen Demokrasi, Jurnal Konstitusi, Vol 3, Nomor 4, Desember 2006).

Seperti yang dikatakan oleh Robert Dahl bahwa 'dua dari enam cirri lembagalembaga politik yang dibutuhkan oleh demokrasi skala besar adalah berkaitan dengan pemilihan umum, yaitu para pejabat yang dipilih dan pemilihan umum yang bebas, adil dan berkala (Dahl, hlm.18)

Office for Democratic Institusions and Human Rights di dalam dokumen International Standards and Commitments on the Right to Democratic Elections mengidentifikasi 10 (sepuluh) komponen Pemilu demokratis berdasarkan kasus - kasus dan instrument internasional. Kesepuluh komponen itu meliputi :

1. Sistem Pemilu (election system);

2. Pengaturan distrik (districting);

3. Administrasi pemilu (election administration);

4. Hak pilih dan pendaftaran pemilih (suffrage rights and voter regristation);

5. Pendidikan pemilih kewarganegaraan dan informasi pemilih (civic education andvoter information);

6. Kandidat, partai politik, dan pendanaan kampanye (candidates, political parties, and campaign spending); 
Jurnal Sosial Humaniora Sigli (JSH)

p ISSN : 2615-3688

$e$ ISSN : 2716-0270

http://journal.unigha.ac.id/index.php/JSH

7. Akses media dan perlindungan kebebasan berbicara dan berekspresi di dalam kampanye (media, acces and protection of freedom of speech and expression)

8. Pemungutan pemilu (balloting);

9. Pemantauan pemilu (election observation);

10. Penyelesaian sengketa pemilu (resolution of election disputes) (Janedjri M. Gaffar, opcit. 14).

\section{Varian Demokrasi}

David Held mengemukakan ada 10 (sepuluh) variasi demokrasi :

1. Classical democracy. Demokrasi ini diterapkan di Negara kota kecil di mana warga Negara menikmati persamaan dan berpartisipasi secara langsung dalam pelaksanaan fungsi legisatif dan yudisial. Dalam demokrasi ini terdapat keharusan adanya mejelis terbuka dengan eksekutif yang diplih langsung, baik dengan pengundian maupun secara bergantian.

2. Protective Democracy. Demokrasi ini ada pada masyarakat dengan kepemimpinan patriarchal yang tealh terorganisasi di mana warga Negara membutuhkan perlindungan dari penguasa dan dari warga yang lain. penguasa memerintah sesuai dengan kepentingan warga dan untuk menjaga kepemilikan pribadi. Model ini disebut protektif karena tujuannya adalah untuk melindungi warga dari kesewenang- wenangan penguasa, melindungi sistem hukum dari para pelanggar aturan hukum.

3. Radical model of Development Democarcy. Demokrasi ini digambarkan ada pada masyarakat non indutri yang merdeka dalam urusan ekonomi dan politik. Warga Negara menikmati persamaan politik dan ekonomi, tidak ada orang yang menjadi bawahan orang lain. lembaga legislative dipilih secara langsung. Eksekutif dijalankan oleh para pegawai yang ditunjuk atau dipilih secara langsung.

4. Developmental Democracy. Sisitem ini ada pada Negara laissez faire yang didukung oleh sistem ekonomi pasar kompetitif dan kepemilikan privat sebagai alat produksi. Dalam model ini politik diperlukan untuk (1) melindungi kepentingan individu, dan (2) kemajuan kelompok terpelajar yang membangun masyarakat.

5. Direct Democracy and the End of politics. Sisitem ini ada pada masyarakat yang kelas pekerjanya mengalahkan kaum borjuis dimana kepemilikan privat dihapuskan dan ekonomi pasar dihilangkan. Negara diselenggarakan untuk mencapai kebebasan semua warga Negara. Urusan public dijalankan dan diatur oleh seluruh anggota komunitas. Semua pegawai dipilih dan dapat dihentikan oleh warga Negara.

6. Competitive Elitist Democracy. Sistem ini ada pada masyarakat dengan kelompok yang saling berkompetisi untuk memperoleh kekuasaan dan keuntungan, sedangkan para pemilih pada umumnya kurang terdidik serta apatis terhadap polotik. Cirri utama dari model ini adalah (a) pemerintahan parlementer dengan eksekutif yang kuat atau pemerintahan presidensial dengan lembaga legislative sebagai pengawas, (b) kompetisi antar kelompok atau partai politik, (c) dominasi partai politik, dan (d) adanya birokrasi yang terlatih.

7. Pluralist Democracy. Demokrasi dalam masyarakat yang beragam di mana masing - masing memiliki tujuan, budaya dan kekuatan masing -masing serta berupaya untuk mendapatkan sesuatu bagi kelompoknya. Karakteristik dari 
model demokrasi ini adalah (1) adanya jaminan kebebasan dan kemerdekaan, (2) adanya instruksi cheks and balances guna menjaga berfungsinya legislative, eksekutif, dan judicial di wilayah masing - masing, (3) adanya sistem pemilihan yang kompetitif, (4) adanya berbagai amcam dan bentuk kelompok kepentingan mencari pengaruh politik, (5) penghormatan terhadap hukum dan konstitusi, dan (6) Negara mencari pemenuhan kepentingannya sendiri, tidak selalu bertindak imparsial.

8. Legal democracy. Demokrasi ini menggambarkan kpemimpinan politik efektif, dipandu prinsip liberal, serta minimalnya peran kelompok-kelompok kepentingan. Karakteristik model ini adalah (1) Negara bekerja berdasarkan konstitusi, (2) rule of law berlaku dan mengalahkan rule of man, (3) masyarakat pasar bebas, dan (4) Negara memiliki peran minimal sedangkan individu memiliki otonomi yang maksimal.

9. Participatory Democracy. Sistem ini menggambarkan masyarakat berkeadilan yang sempurna dengan sumber daya yang tersedia bagi semua orang serta keterbukaan dan informasi dipastikan dapat dikases oleh setiap orang. Cirri cirri model ini meliputi (a) warga Negara berpartisipasi langsung dalam setiap institusi social, (b) kepemimpinan partai bertanggungjawab kepada anggota partai, dan (c) dijalankannya sistem kelembagaan terbuka untuk memastikan kesempatan eksperimentasi bentuk bentuk politik.

10. Democracy Autonomy. Sistem yang berjalan jika terdapat keterbukaan informasi untuk memberitahukan keputusan -keputusan public, menyusun prioritas pemerintahan, termasuk mengatur pasar. Model ini mencita - citakan kebebasan dan kesamaan kondisi dan otonomi bagi kehidupan setiap individu serta menjamin hak dan kewajiban yang sama. Karakteristik model ini meliputi (1) otonomi diabadikan dalam konstitusi, (2) sistem kepataian yang kompetitif, dan (3) pelayanan administrasi diorganisasikan secara internal sesuai mprinsip partisipasi langsung (Janedjri M. Gaffar. Opcit. Hlm. 17 -20).

Dari berbagai pengertian dan praktik demokrasi yang ada, secara teoritis menjadi dua konsepsi, yaitu demokrasi deliberative dan demokrasi elit.Demokrasi debliberatif merupakan demokrasi yang dikonsepsikan secara idealis, teoritis, dan top down. Sedangkan demokrasi elit mengonsepsikan demokrasi secara pragmatis sebagai kompetisi perebutan kekuasaan oleh elit politik untuk mendapatkan dukungan massa (Janejdri m. Gaffar, ibid. hal 20).

Dari berbagai perspektif yang ada, di era modern demokrasi mempunyai arti penting bagi masyarakat karena memberikan hak kepada rakyat untuk menentukan sendiri jalannya organisasi Negara. Dari ide dasar ini dan praktik demokrasi yang berbeda- beda, Moh. Mahfud MD menyatakan bahwa demokrasi sebagai dasar hidup bernegara memebri pengertian bahwa pada tingkat terakhior rakyat memberikan keputusan dalam masalah - masalh pokok kehidupannya, termasuk dalam menilai kebijaksanaan Negara, karena kebijaksanaan tersebut menentukan kehidupan rakyat ( Moh. Mahfud MD, Hukum dan Pilar -Pilar Demokrasi, hal, 7-8).

\section{Pemilu berintegritas}

Pemilu berintegritas sebagai pemilu yang berdasarkan atas prinsip demokrasi dari hak pilih universal dan kesetaraan politik seperti yang dicerminkan pada standar 
internasional dan perjanjian, professional, tidak memihak dan transparan dalam persiapan dan tantangan utama pemilu berintegritas pengelolaannya melalui siklus pemilu.

Pemilu berintegritas dapat diwujudkan dengan membangun hal- hal sebagai berikut:

1. Membangun peraturan hukum untuk membenarkan klaim terhadap hak asasi dan keadilan pemilu;

2. Membangun badan penyelenggara pemilu berkompeten dengan kebebasan penuh dalam bertindak untuk menyelenggarakan pemilu yang transparan dan mendapatkan kepercayaan public yang layak;

3. Menciptakan institusi dan norma persaingan multi- partai serta pembagian kekuasaan yang menunjang demokrasi sebagai sistem keamanan bersama di antara para pesaing politik;

4. Menghilangkan hambatan hukum. Adminbstratif, politik, ekonomi dan social terhadap partisiupasi politik yang setara dan universal;

5. Mengatur keuangan politik yang tak dapat dikendalikan, tertutup dan samar.

Selanjutnya, diperlukan komitmen semua pemangku kepentingan dalam mewujudkan pemilu berintegritas berupa tindakan yang saling menguatkan ;

1. Antara pemerintah dan warga Negara

2. Antar pemerintah yang berpendirian;

3. Membangun ketaatan hukum dalam rabngka memastikan warga negaranya, termasuk pesaing politik dan oposisi, memiliki perlindunagn hukum untuk menjalankan hak mereka yang berhubungan dengan pemilu;

4. Menghasilkan penyelenggara pemilu yang professional dan kompeten dengan kebebasan penuh dalam bertindak, termasuk penjaminan akses yang tepat waktu ke keuangan yang diperlukan untuk menyelenggarakan pemilu, dan mandate untuk mengelola pemilu yang transparan, yang pantas menerima kepercayaan public;

5. Mengembangkan lembaga, proses dan jejaring yang menghalangi kekerasan berkaitan pemilu dan jika pencegahan gagal, pelaku kejahatan harus bertanggung jawab;

6. Pembaharuan dan mendesaian sistem pemilu dan menerapkan kebijakan untuk menguarangi "pemenang pokitik yang memperoleh segalanya"/ politik "winnertake- all";

7. Menghilangkan rintangan pada partisipasi perempuan, kaum muda, minoritas, warga penyandnag cacat dan kelompok marginal tradisional lainnya, serta mengambil langkah tegas untuk memajukan kepemimpinan dan partisipasi perempuan yang luas, termasuk mela;ui penggunaan kouta yang bijak;

8. Mengontrol keuangan politik dengan mengatur donasi dan pengeluaran, pembiayaan public atas kampanye politik, pelap[oran dan transparansi donasi dan pengeluaran, srta sanksi dan penalty bagi yang tidak mematuhi (Global Commision on Elections, Democracy and Security, hal 22-27).

Keadilan Pemilusistem keadilan pemilu merupakan instyrumen penting untuk menegakkan hukum dan menjamin sepenuhnya penerapan prinsip demokrasi melalui pelaksanaan pemilu yang bebas, jujur, dan adil.

Sistem keadilan pemilu harus dipandang berjalan efektif, serta menunjukkan independensi dan imparsialitas untuk mewujudkan keadilan, transparansi, aksebilitas.Inklusivitas, dan kesetaraan.

Sistem keadilan pemilu dikembangkan untuk mencegah dan mengidentifikasikan 
berbagai pelanggraan, kecurangan dan ketidakberesan pada pemilu, sekaligus sebagai sarana dan mekanisme untuk membenahi pelanggran dan ketidakberesan tersebut dan memberikan sanksi kepada pelaku pelanggaran lewat mekanisme penegakan hukum dan keadilan pemilu.

Setiap tindakan, prosedur, atau keputusan menyangkut proses pemilu yang tidak sesuai dengan undnag-undang termasuk katagori pelanggaran ataupun ketidakberesan, baik itu pelanggaran adminstrasi, pidana pemilu maupun pelanggran kode etik kepemiluan. Mengingat bahwa pelanggran dan ketidakberesan dalam proses pemilu dapat menimbulkan sengketa, sistem keadilan pemilu berfungsi untuk mencegah terjadinya berbagai tinddak kecurangan dan pelanggaran yang dapat mengurangi makna dan kwalitas kedaulatan rakyat. Kecurangan pada penyelenggaraan pemilu mesti dicegah dengan semangat dan komitmen semua pihak, baik penyelenggara, peserta maupun pemerintah. Proses penegakan hukum kepemiluan diperlukan guna menjamin pemilu yang bebas, adil, dan jujur. Oleh karena itu, desain ssitem keadilan pemilu yang akurat sangat penting untuk menjamin legitimasi demokrasi dan kredibilitas proses pemilu.

Konsep keadilan pemilu tidak hanya terbatas pada penegakan kerangka hukum, tetapi juga merupakan salah satu faktor yang perlu diperhatikan dalam merancang dan menjalankan seluruh proses pemilu sesuai dengan azas - azas penyelenggaraan pemilu. Keadilan pemilu juga merupakan faktor yang mempengaruhi prilaku para pemangku kepentingan dalam proses tersebut. Karena sistem keadilan pemilu sangat dipengaruhi kondisi sosial,-budaya, konteks sejarah dan politik Negara, maka sistem dan praktiknya mestilah berasas pada prinsip penegakan hukum secara universal, sehingga manfaat, kepastian serta keadilan sebagai cita - cita hukum benar- benar hadir dan dirasakan oleh semua pihak saat pemilihan umum diselenggarakan.

Sistem keadilan pemilu perlu mengikuti sejumlah norma dan undangundang serta nilai tertentu agar proses pemilu lebih kredibel dan memilki legitimasi yang tinggi.norma dan nilai ini bersumber pada peraturan perundang-undangan, budaya dan kerangka hukum melalui sebuah proses penegakan hukum yang transparan dan akuntable.

Sistem keadilan pemilu dipandang berjalan efektif, serta menunjukkan independensi dan imparsialitas untuk mewujudkan keadilan, transparansi, aksesbilitas, serta kesetaraan dimata hukum. Apabila sistem ini dipandang tidak kokoh dan tidak berjalan dengan baik, kredibilitasnya akan berkurang dan dapat mengakibatkan peserta pemilu dan pemilih mempertanyakan makna penegakan hukum, atau bahkan adanya gelombang penolakan hasil pemilu. Dengan demikian, keadilan pemilu yang efektif dan tepat waktu menjadi elemen kunci dalam menjaga kredibilitas dan integritas proses serta hasil pemilu.

Keadilan pemilu dimaknai sebagai tindakan :

1. Menjamin bahwa setiap tindakan, prosedur, dan keputusan terkait dengan pemilu sesuai dengan kerangka hukum;

2. Melindungi hak pilih serta kepentingan peserta pemilu yang setara

3. Memungkinkan peserta pemilu dan pemilih yang meyakini bahwa hak mereka telah dialnggar untuk mengajukan pengaduan, mengikuti persidangan, dan mendapatkan putusan (IDEA, CETRO, hal 5, Jakarta. 2010).

Menurut International Institute For Democracy and electoral Assistance ada tiga jenis mekanisme utama untuk menyelesaikan sengketa pemilu :

a. Mekanisme formal atau korektif (misalnya mengajukan dan memproses gugatan pemilu): jika dilaksanakan, 
mekanisme ini akan menghasilkan keputusan membatalkan, mengubah, atau mengakui adanya ketidakberesan dalam proses pemilu;

b. Mekanisme penghukuman atau punitif (misalnya dalam kasus pelanggaran pidana): jika dilaksanakan, mekanisme ini akan menjatuhkan sanksi kepada pelanggar, baik badan maupun individu yang bertanggung jawab atas ketidakberesan tersebut, termasuk tanggung jawab (liability) pidana atau adminstratif terkait dengan pemilu; dan

c. Mekanisme alternative: mekanisme ini dapat dipilih oleh pihak-pihak yang bersengketa ( Keadilan Pemilu, hal, 6. 2010).

Sistem penyelesaian sengketa pemilu sebagai bagian dari sistem keadilan pemilu perlu memastikan bahwa seluruh tindakan dan keputusan yang diambil sepanjang siklus pemilu sesuai dengan amanat undangundang. Hal ini diperlukan terutama apabila mandate badan penyelesaian sengketa terbatas sepanjang masa pemilu saja. Seluruh sistem penyelesaian sengketa pemilu perlu mengadopsi prinsip bahwa gugatan pemilu harus diajukan pada periode pemilu saat tindakan yang digugat terjadi.Oleh karena itu, tindakan atau keputusan yang tidak digugat selama periode tertentu bersifat final dan tidak dapat lagi dipermasalahkan. Praktik ini ditempuh untuk menjamin agar setiap tahapan pemilu dapat berjalan tanpa hambatan sehingga proses pemilu dapat berjaaln dengan lancer.

\section{Sistem penyelesaian sengketa pemilu}

Istilah sistem penyelesaian sengketa pemilu merujuk pada kerangka hukum yang memuat mekanisme sistem keadilan pemilu secara detail yang dirancang untuk menyelesaikan sengketa pemilu dan menjamin hak pilih warga Negara.
Sistem penyelesaian sengketa pemilu dibentuk untuk menjamin integritas proses pemilu. Melaui sistem penyelesaian sengketa pemilu, tindakan yang dilakukan dalam proses pemilu yang betentangan dengan hukum dapat dibatalkan atau diubah melalui proses pengajuan gugatan atau pengaduan. Pelaku pelanggran atau orang yang bertanggung jawab atas terjadinya ketidakberesan dalam pemilu juga dapat dikenai sanksi.

Gugatan pemilu adalah pengaduan yang disampaikan oleh peserta pemilu atau pemangku kepentingan lain yang meyakini bahwa hak pilihnya telah dilanggar. Gugatan pemilu yang bersifat korektif berfungsi untuk menjamin proses pemilu dijalankan sesuai dengan undang-undang;agar kesalahan atau ketidakberesan pemilu dapat diketahui, diubah, dibataklkan atau diperbaiki; dan agar hak pilih dapat dijamin atau dipulihkan.

Sistem penyelesaian sengketa pemilu juga berfungsi menjaga legalitas proses pemilu, yaitu dengan menerapkan mekanisme pemberian sanksi (punitif) bagi pihak yang melakukan pelanggran dan yang bertanggung jawab mencegah terjadinya pelanggaran. Sanksi ataupun koreksi diberikan sesuai peraturan perundangundangan lewat mekanisme penyelesaian sengketa kepemiluan. Adanya jaminan penerapan sanksi akan membangun proses serta menghasilkan hak pilh rakyat yang berintegritas.

Dalam mewujudkan pemilu berintegritas, penegakan hukum kepemiluan berfungsi untuk mencegah pelanggaran, mengawasi proses pemilu dan menjaga agar pemilu berlangsung sesuai prinsip dan azas pemilu, langsung, umum, bebas, rahasia serta jujur dan adil.

\section{Varian pelanggaran kepemiluan}

Ada tiga bentuk pelanggaran dalam pelaksanaan pemilu yang sering terjadi. Yaitu:

1. Pelanggaran adminstrasi. Pelanggaran ini berupa tindakan atau kelalaian yang dapat 


\begin{abstract}
dikenakan sanksi administrasi berupa pembatalan atau korektik terhadap putusan yang berkaitan dengan mekanisme dan prosedur kepemiluan. Pelanggaran administrasi dapat berupa tindakan atau kelalaian penyelenggara pemilu, calon, pemantau atau pemilih. Untuk pelanggaran administrasi, badan yang diberikan kewenangan untuk penyelesaian sengketa akan melakukan penyelidikan dan menjatuhkan sanksi adminstratif sesuai dengan ketentuan dan kerangka hukum.
\end{abstract}

2. Pelanggaran pidana. Sanksi atas pelanggran pidana dalam proses pemilu melalui sistem penyelesaian tindak pidana yang melibatkan badan pengawas pemilu, kepolisian, kejaksaan di peradilan pidana. Tindak pidana kepemiluanyang dilakukan baik oleh penyelenggara, peserta pemilu, pemilih maupun pejabat pemerintah yang melakukan pelanggaran.

3. Pelanggaran kode etik. Pelanggaran kode etik ini diberikan kepada penyelenggra pemilu yang melakukan perbuatan yang mencederai independensi dan profesionalitas penyelenggaraan pemilu. Putusan penerapan sanksi kode etik ini dilakukan oleh sebuah dewan kehormatan penyelenggra pemilu, guna menjaga integritas lembaga penyelenggara pemilu dari perbuatan dan moral rendah.

\section{Jajaran Penyelenggara Pemilu}

Menurut Undang - Undang No 7 tahun 2017, tentang peyelenggaraan Pemilu disebutkan jajaran penyelenggara pemilu yang terdiri dari Komisi Pemilihan Umum (KPU), Badan Pengawas Pemilu (Bawaslu), dan Dewan Kehormatan Penyelenggara Pemilu (DKPP).

Sebagai administrator utama Pemilu, KPU beserta jajarannya, KPU Prov, KPU
Kab/Kota, Panitia Pemilihan Kecamatan (PPK), Panitia Pemungutan Suara (PPS), dan Kelompok Penyelenggara Pemungutan Suara (KPPS), diberikan kewenangan, tugas dan kewajiban menyelenggaran Pemilu dari sisi teknis dan terselenggaranya pemilihan. Kegiatan pemilihan berlangsung sesuai dengan tahapan- tahapan, mulai dari tahapan persiapan, sosialisasi, pendidikan pemilih, pendaftaran peserta Pemilu, pemuktakhiran data pemilih, kampanye, penyediaan logistic berupa, surat suara, bilik suara, kotak suara, formulir pencatatan serta pemungutan, penghitungan dan rekapitulasi suara di semua jenjang. Keberhasilan Pemilu terlihat dari terisinya semua lembaga yang dipilih melalui Pemilihan Umum.

Badan Pengawas Pemilu, secara structural terdiri dari Bawaslu, Bawaslu Prov, Bawaslu Kab/kota, Panitia Pengawas Kecamatan (Panwascam), Pengawas Desa, dan Pengawas Tingkat TPS (Tempat Pemungutan Suara). Secara fungsionalitas, Bawaslu dirancang pembentuk undang undang untuk pengembangan fungsi "pengimbangan dan pengawasan" (checks and balances) terhadap kinerja jajaran KPU serta diberi kewenangan untuk menyelesaikan sengketa atau pelanggran yang bersifat pelanggran administrative.Bawaslu memiliki peran sebagai penjamin kualitas penyelenggaraan Pemilu (quality assurance).Tanggung jawab Bawaslu pararlel dengan tanggung jawab KPU.

Dewan Kehormatan Penyelenggara Pemilu (DKPP), secara fungsional sebagai lembaga menjaga dan menegakkan prinsip kemandirian, integritas dan kredibilitas jajaran KPU dan Bawaslu (Nurhidayat Sardini, Serial Evaluasi Penyelenggaraan Pemilu serentak Tahun 2019, hal. 231- 235).

Lahirnya pemilu berintegritas sangat tergantung pada lembapa penyelenggara pemilu tersebut, pembentuk undang- undang telah memberikan kewenangan, hak serta kewajiban bagi lembaga - lembaga tersebut 
Jurnal Sosial Humaniora Sigli (JSH)

p ISSN : 2615-3688

$e$ ISSN : 2716-0270

http://journal.unigha.ac.id/index.php/JSH

untuk menyelenggarakan pemilihan umum sebagai perwujudan kedaulatan rakyat.

Menurut Robins, sebuah organisasi dapat dengan berhasil menjalankan misinya jika memilki kketerampilan dasar (basic literacy skill), keterampilan teknik (technical skill), keterampilan interpersonal (interpersonal skill), dan kemampuan dalam memecahkan masalh (problem solving skill) (Nurhidayat Sardini, ibid. hal.25

\section{Simpulan dan Saran}

Pemilu berintegritas lahir dari penyelenggara, peserta/calon serta pemilih yang berintegritas pula. Pemilu yang berintegritas akan memberikan legitimasi kuat bagi mereka yang terpilih dalam mewujudkan cita - cita kesejahteraan dan kemakmuran rakyat sebagaimana yang dicantumkan dalam konstitusi Republik Indonesia. Adanya berbagai ketidak beresan dalam proses Pemilu dapat melahirkan berbagai sengketa, yang pada akhirnya menimbulkan konflik sosial yang berkepanjangan. Penegakan hukum dan keadilan Pemilu merupakan hal yang mutlak dilaksanakan oleh komponen penyelenggara Pemilu.Kesiapan pemerintah sebagai pembentuk undang- undang kepemiluan menghendaki seperangkat aturan yang aplikatif dan sesuai dengan kaidah universal guna membangun keadilan pemilu dalam kerangka hukum nasional.

\section{Daftar Pustaka}

Aditya Perdana (edt), Serial evaluasi Penyelenggaraan Pemilu Serentak 2019, Bawaslu, Jakarta, 2019.

Burhanuddin Muhtadi, Kuasa Uang, Politik Uang Dalam Pemilu Pasca Orde Baru, KPG, Jakarta, 2020

Fritz Edward Siregar, Menuju Peradilan Pemilu, themis Publishing, Jakarta, 2018.

Global Comimision, Pendalaman Demokrasi, Strategi Untuk Meningkatkan Integritas Pemilihan Umum di Seluruh Dunia, 2012.

IDEA, Keadiloan Pemilu, CETRO, Jakarta, 2010.

Janedjri M. Gaffar, Demokrasi dan Pemilu Di Indonesia, KonPres, Jakarta, 2013

Jimly Asshidiqie, Konstitusi \& konstitusionalisme Indonesia, KonPres, Jakarta. 2006

Titi Anggraini, Menata Kembali Pengaturan Pemilukada, Perludem, Jakarta, 2011. 